\title{
Three-Dimensional Analysis of the Atrophic Process of Rat Seminiferous Tubules after Estradiol Treatment
}

\author{
Masao Hamasaki and Masahiro Murakami \\ Department of Anatomy, Kurume University School of Medicine, Kurume, Japan \\ Received December 20, 1991
}

Summary. Atrophic changes in the basal portion of the seminiferous tubules caused by daily injections of estradiol have been found by scanning electron microscopy disclosed after a digestion technique using collagenase and trypsin

In the control rat, the smooth basal portion of the epithelium was composed of polygonal Sertoli cells and reticularly-arranged ovoidal spermatogonia. After estradiol treatment, there appeared wavy furrows and ridges, and many folded micro-wrinkles in the complicated basal portion of the seminiferous tubules. The wavy furrows and ridges were repeatedly formed and appeared just like a cornice. These structures ran in an orderly manner perpendicular to the longitudinal axis of the tubules. In contrast, many micro-wrinkles ran in parallel to the longitudinal axis. These two structures had a characteristically similar size and orderly arrangement. They are discussed in relation to the mechanism by which the seminiferous tubules shrink by injections of estradiol.

Spermatogenesis in mammals has been dramatically inhibited by treatment with estradiol (STEINBERGER, 1971; Chemes et al., 1976; Lu and STEINBERGER, 1978). It has been also clarified by light and/or transmission electron microscopy that the seminiferous tubules are shrunk with irregular basal profiles and that the basement membrane gradually increases in thickness. However, there are no morphological reports about the shrinkage process of the seminiferous tubules.

We have examined some morphological changes accompanying the atrophic process of the seminiferous tubules induced by estradiol treatment.

\section{MATERIALS AND METHODS}

Estradiol was subcutaneously injected in the Wistar adult rats at a concentration of $0.5 \mathrm{mg} / 0.5 \mathrm{ml} /$ day for 16 or 32 days. As to scanning electron microscopy (SEM) with a disclosing technique, the fresh testicular blocks from these animals were digested in 0.1 $\mathrm{M}$ phosphate buffer containing $170 \mathrm{I} . \mathrm{U}$. collagenase and 40 I.U. trypsin at $37^{\circ} \mathrm{C}$ for $60 \mathrm{~min}$. They were fixed in $2.5 \%$ glutaraldehyde and $2 \%$ formaldehyde/ $0.1 \mathrm{M}$ cacodylate buffer ( $\mathrm{pH} 7.4$ ), dehydrated in a graded series of aceton, critical-point-dried, and observed with a Hitachi field emission SEM (HFS-II).

\section{RESULTS}

When fresh blocks of testis were enzymatically digested, the basal portion of the seminiferous epithelium was widely disclosed and, as a result, easily observed with SEM. In the control rats, the basal portion of the epithelium showed a smooth surface and was composed of polygonal Sertoli cells and reticularly-arranged, ovoid spermatogonia (Fig. 1). At 16 days of injections, the short micro-wrinkles were first partially oriented in the basal portion of the Sertoli cells (Fig. 2). They were longer and more complicated at 32 days of injections (Fig. 3). Such micro-wrinkles were formed on the basal surfaces of Sertoli cells and spermatogonia and showed a characteristically similar size and constant direction. They were found running in parallel to the longitudinal axis of the tubule. On the other hand the wavy furrows and ridges were not found at 16 days of injection, but were completed at 32 days. They were located running perpendicularly to the longitudinal axis of the tubule, and looked like a bellow or cornice as a whole (Fig. 4). The direction of wavy furrows and ridges was perpendicular to that of the microwrinkles. 


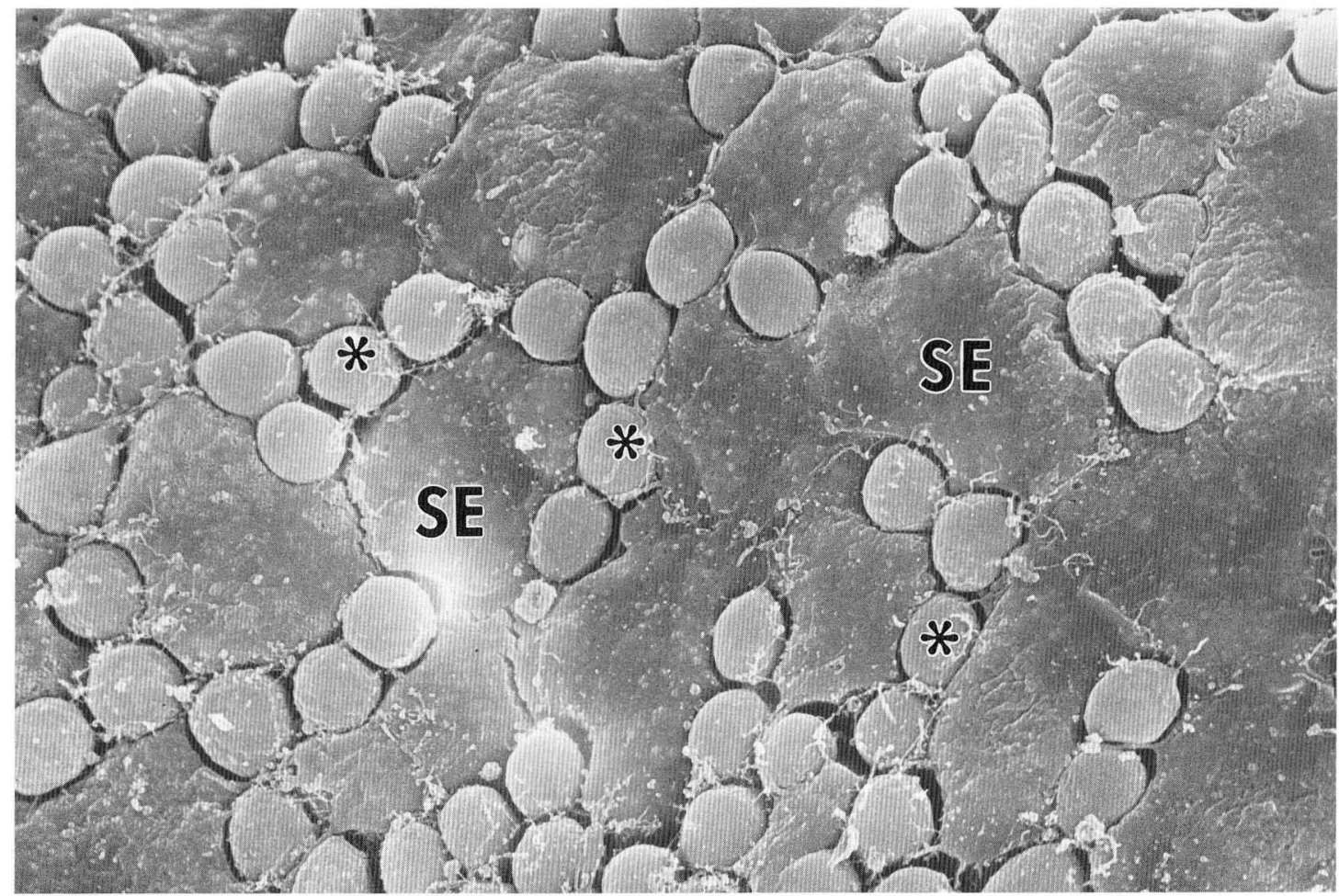

Fig. 1. Basal portion of the seminiferous epithelium is smooth in contour in the control rat. Sertoli cells $(S E)$ and spermatogonia $(*) \times 1,700$

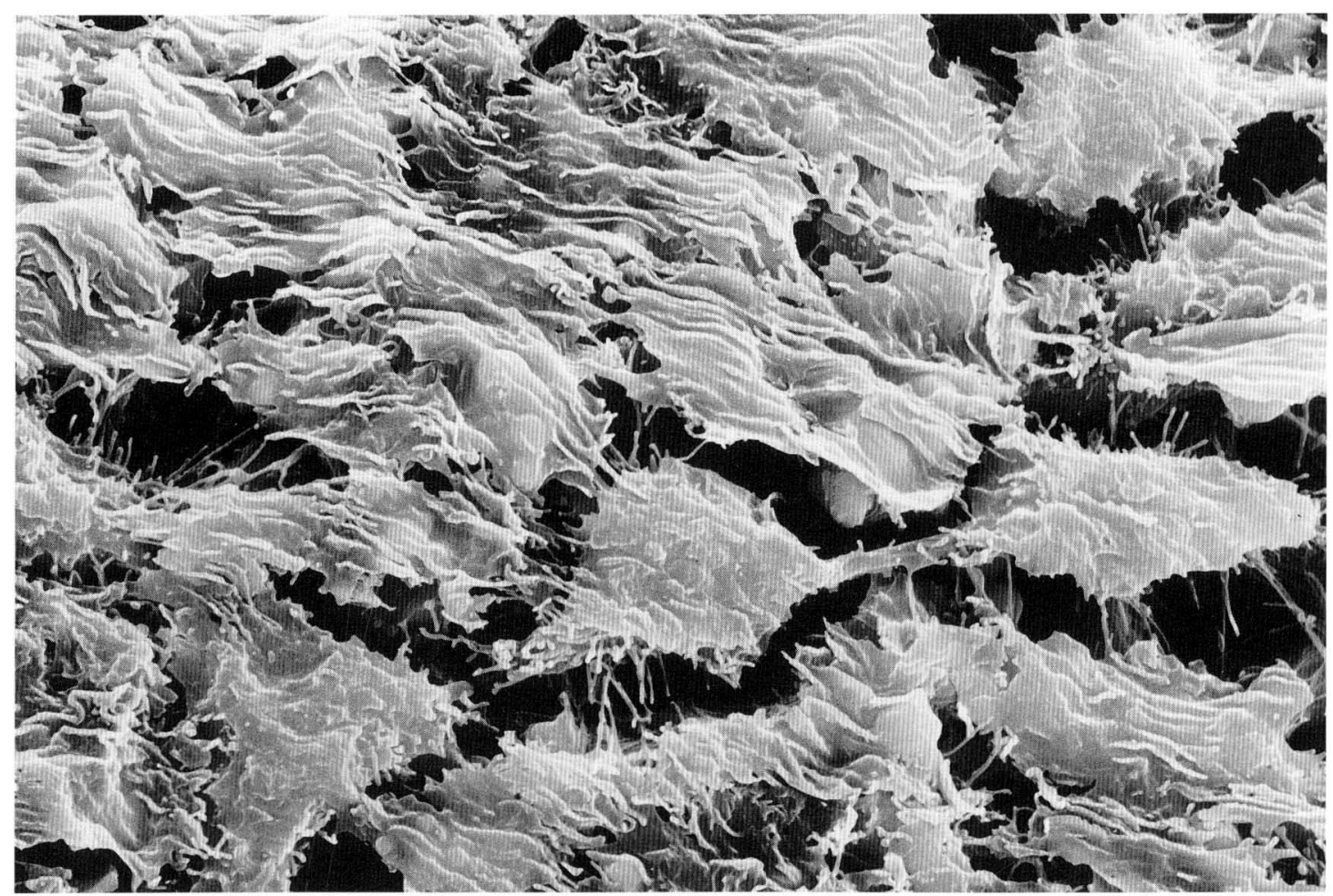

Fig. 2. Short micro-wrinkles are first formed at 16 days of injections. $\times 2,000$ 


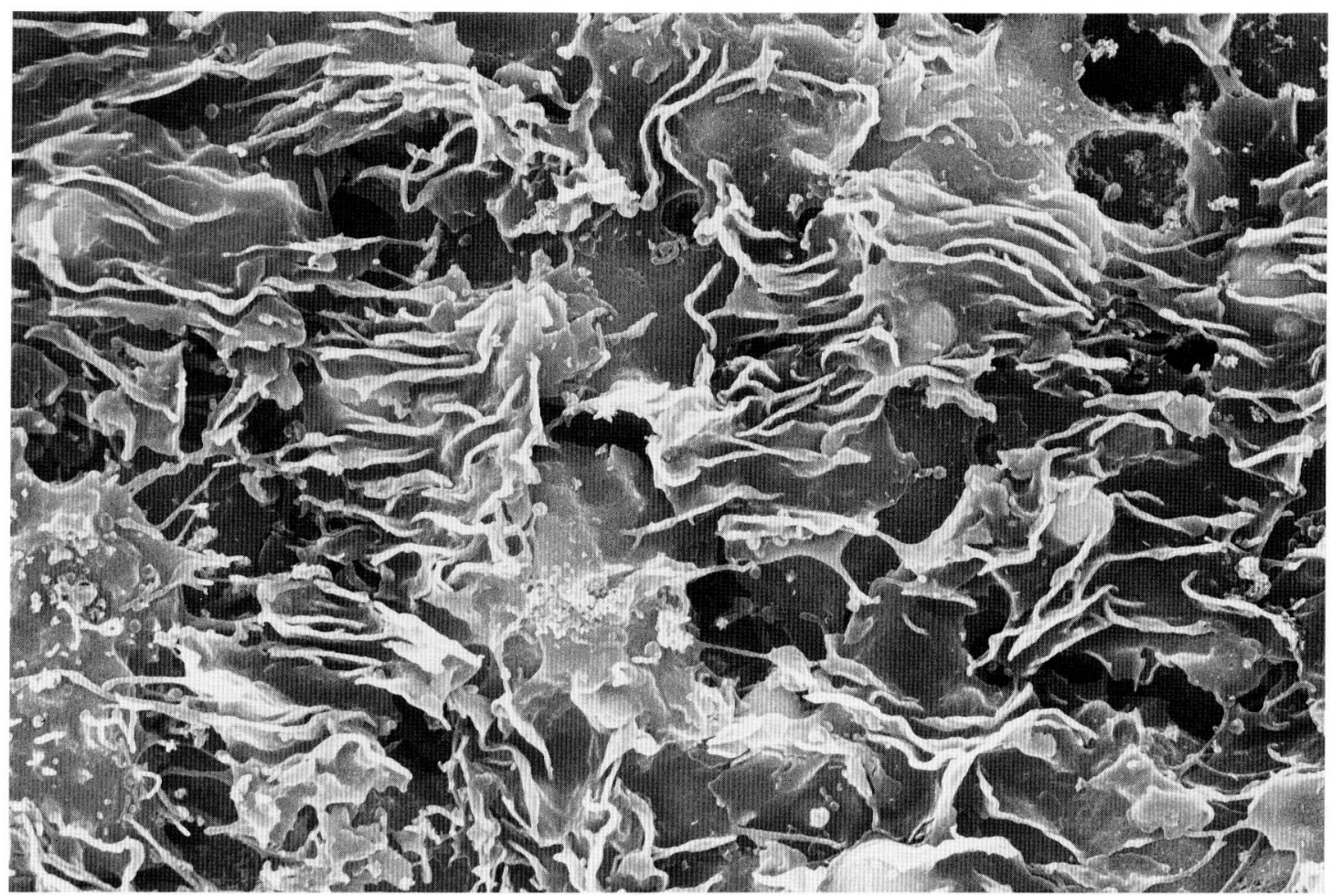

Fig. 3. The large micro-wrinkles are more elongated and more increased in number at 32 days of injections. $\times 3,800$

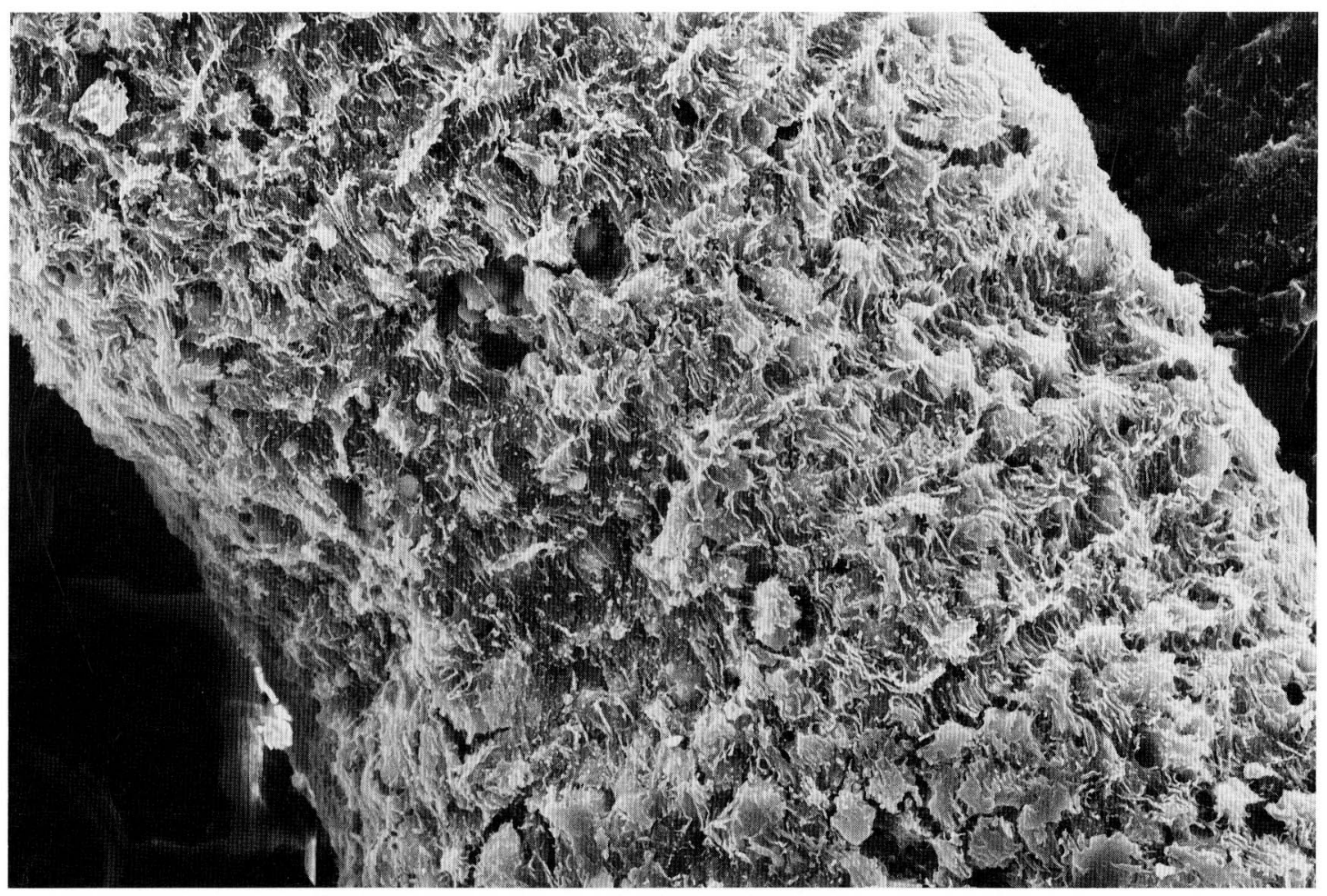

Fig. 4. Many wavy furrows and ridges are revealed in the basal portion of the epithelium at 32 days of injections. $\times 650$ 


\section{DISCUSSION}

Spermatogenesis is inhibited by the administration of estradiol (LU and STEINBERGER, 1978), oestrogen (VENIZELOS and PARADINAS, 1988), ethylene glycol monomethyl ether (LEE and KINNEY, 1989), gossypol (HOFFER, 1983) and ethylene-1, 2-dimethanesulphonate (ZAIDI et al., 1988), and by immunization with laminin (LusTIG et al., 1987; ARECES et al., 1989). All reports have stated that spermatogenesis is markedly inhibited after treatment with estradiol. However, shrinkage of the seminiferous tubules has been less emphasized.

After a daily injection of estradiol, the following morphological changes were observed during the shrinkage process of the seminiferous tubules. First, there appeared short micro-wrinkles in the basal portion of the Sertoli cells at 16 days of injections. They were longer and more complicated forming many folded lines over the whole basal portion of the adjoining Sertoli cells in many tubules at 32 days. These larger micro-wrinkles were characteristic in size and showed a constant direction. Secondly, the wavy furrows and ridges were found only at 32 days, running circularly or perpendicularly to the longitudinal axis of the tubules. They looked like a bellow or cornice as a whole. Such morphological changes had a regular size and orderly direction. They were first observed with SEM, but could not be clarified with TEM.

It remains unclear how these changes occur and why they are arranged in an orderly manner. One possible factor is mutual replications by the contractile cells which are repeatedly evaginated or invaginated after estradiol treatment. However, this is not reasonable because there is a marked difference in size and arrangement between the contractile cells and the Sertoli cells. Another factor is probably synchronization of the epithelial cell components; germ and Sertoli cells. It is well known that the adjoining germ cells during their cell cycle are functionally synchronized through the intercellular bridges (MORALES and GRISWOLD, 1987; LOK and DE RooIJ, 1983). These orderly features suggest that synchronization may exist not only in the adjoining germ cells but also in the adjacent Sertoli cells. Namely, the specialized Sertoli-Sertoli junctional complex possibly functions in synchronization just as the intercellular bridge does in the germ cells.

A functional role for these morphological changes may be considered as follows. Many lines of the micro-wrinkles were oriented in parallel to the longitudinal axis of the tubules. They probably function to decrease the diameter of the seminiferous tubules. The decrease of diameters is possibly related to the size and number of the micro-wrinkles. In addition, the wavy furrows and ridges were found only at 32 days of injections, running circularly or perpendicularly to the longitudinal axis of the tubules, just like a bellow. The seminiferous tubules may be decreased in length by formation of the wavy furrows and ridges like a bellow. So, it is believed that, after estradiol treatment, the seminiferous tubules first decrease in diameter by formation of the microwrinkles, and then shorten by secondary formation of the wavy furrows and ridges.

A concavo-convex relationship between furrows and ridges is clear for the atrophic brain which is decreased in volume (ANDREW, 1971). In such a case, the furrows of the brain cortex became deeper and larger than those of the normal cortex. The wavy furrows and ridges, and many folded lines of the micro-wrinkles were also observed in the modified Sertoli cells in the terminal segment of the seminiferous tubule (DYM, 1974; YoKoYAMA, 1986). These structures are possibly correlated with formation of the sharply narrowed tubules.

This SEM study following an enzymatic digestion technique first clarified the regular morphological changes and mechanically analyzed the atrophic process of the seminiferous tubules after a daily injection of estradiol.

\section{REFERENCES}

Andrew, W.: The nervous system, Part III. Man and mammals. In: (ed. by) W. ANDREw: The anatomy of aging in man and animals. Grune \& Stratton, New York and London, 1971 (Chap. 20, p. 218-238).

Areces, L. B., M. B. DE J. Bonino, O. Cascone, R. Puig and B. Denduchis: Antigenicity of basement membrane fractions obtained from rat seminiferous tubules. Amer. J. Immunol. 20: 117-122 (1989),

Chemes, H. E., E. Podesta and M. A. Rivarola: Action of testosterone, dihydrotestosteron and $5 \alpha$ androstane $3 \alpha, 17 \beta$ Diol on the spermatogenesis of immature rats. Biol. Reprod. 14: 332-338 (1976)

Dyм, M.: The fine structure of monkey Sertoli cells in the transitional zone at the junction of the seminiferous tubules with the tubuli recti. Amer. J. Anat. 140: 1-26 (1974).

Hoffer, A. P.: Effects of gossypol on the seminiferous epithelium in the rat: a light and electron microscope study. Biol. Reprod. 28: 1007-1020 (1983).

LEE, K. P. and L. A. Kinney: The ultrastructure and reversibility of testicular atrophy induced by ethylene glycol monomethyl ether (EGME) in the rat. Tox. Pathol. 17: 759-773 (1989). 
LoK, D. and D. G. De RooIJ: Spermatogonial multiplication in the Chinese hamster. I. Cell cycle properties and synchronization of differenting spermatogonia. Cell Tiss. Kinet. 16: 7-18 (1983).

Lu, C. C. and A. Steinberger: Effects of estrogen on human seminiferous tubules: Light and electron microscopic analysis. Amer. J. Anat. 153: 1-14 (1978).

Lustig, L., G. F. Doncel, E. Berensztein and B. DenDuchis: Testis lesions and cellular and humoral immune responses induced in rats by immunization with laminin. Amer. J. Reprod. Immunol. Microbiol. 14: 123-128 (1987).

Morales, C. and M. D. GRISwold: Retinol-induced stage synchronization in seminiferous tubules of the rat. Endocrinology 121: 432-434 (1987).

STEINBERGER, E.: Hormonal control of mammalian spermatogenesis. Physiol. Rev. 51: 1-22 (1971).

Venizelos, I. D. and F. J. Paradinas: Testicular atrophy after oestrogen therapy. Histopathology 12: 451454 (1988).
Yoкоуама, R.: Ultrastructure of the terminal segment of the seminiferous tubule in the rat. Kurume Igakuzashi 49: 1450-1465 (1986).

ZAIDI, A., R. G. Lendon, J. S. Dixon and I. D. MorRis: Abnormal development of the testis after administration of the Leydig cell cytotoxic ethylene-1, 2-dimethanesulphonate to the immature rat. J. Reprod. Fert. 82: 381392 (1988).

Dr. Masao HAMASAKI Department of Anatomy Kurume University School of Medicine 67 Asahimachi, Kurume Fukuoka, 830 Japan 